\title{
Effects of flavonol quercetin on activity of lipid peroxide oxidation in experimental bacterial-immune periodontitis
}

\author{
ANDRII DEMKOVYCH* \\ Department of Prosthetic Dentistry, Ivan Horbachevsky Ternopil State Medical University, Ternopil, Ukraine \\ *Corresponding address: Andrii Demkovych, PhD, Associate Professor; Department of Prosthetic Dentistry, Ivan Horbachevsky Ternopil State \\ Medical University, Chehova str., 7, Ternopil 46000, Ukraine; Phone: +380 979 342501; Fax: +380 352 524183; \\ E-mail: demkovushae@tdmu.edu.ua
}

(Received: February 26, 2018; Revised manuscript received: March 21, 2018; Accepted: October 10, 2018)

\begin{abstract}
The article presents the results of lipid peroxidation activity in blood serum, which were assessed on the base changes in the level of oxidative modification of proteins, TBA-active products, and total amount of nitrogen (II) oxide metabolites $\left(\mathrm{NO}_{2}{ }^{-}+\mathrm{NO}_{3}{ }^{-}\right)$. Indices were determined on the $14^{\text {th }}$ day of development in experimental periodontitis both without correction, and in condition treatment with a water-soluble flavonol quercetin (corvitin). The treated animals take intramuscular injections of corvitin in a dose $100 \mathrm{mg} / \mathrm{kg}$ weight for $7 \mathrm{days}$. For further testing, blood serum was selected. The results were statistically analyzed using parametric and non-parametric indices. In this investigation, characterized dynamics of changes in the indices of oxidative processes activity were revealed both during the period of formation and the course of periodontitis. In particular, it was found that, for the period of the most expressed inflammatory reaction in the periodontal complex, intensive increase in the level of reactive forms of oxygen. The treatment with flavonol quercetin for 7 days resulted in stabilization of free radical processes and the suppression of the inflammatory reaction.
\end{abstract}

Keywords: periodontitis, quercetin, TBA-active products, nitrogen (II) oxide, oxidative modification of proteins

\section{Introduction}

Improvement and innovation of new methods in periodontitis treatment are one of the essential tasks in the field of modern dentistry $[1,2]$. Inflammatory process in the periodontal complex tissues is most common among diseases of the maxillofacial site $[3,4]$. The leading role inhibits oxidation processes (as initiating factors) and pathogenic microflora, their associations, in particular Staphylococcus and Streptococcus, which result in reduced resistance of the oral tissues to infectious agents $[5,6]$. Activation of lipid peroxidation (LPO) is one of the triggering mechanisms of stress damage with the disorder of the cellular metabolism, which is primarily associated with the damage to cellular and subcellular membranes [7-10]. To neutralize excess LPO and maintain a steady intracellular concentration of free radicals and lipoperoxidum, there is an antioxidant defense system in the body $[11,12]$. In recent years, much attention has been paid to the substances of plant origin polyphenols as antioxidants; in particular, it is known that the flavonol quercetin has an antioxidant, anti-ischemic, membranestabilizing, and immunomodulating effect $[13,14]$. The active substance of this drug is a complex of quercetin with polyvinylpyrrolidone. Quercetin is an antioxidant that effectively regulates energetic metabolism in the myocardium, reduces its requirement in oxygen, stabilizes the cytoplasmic membrane, and causes anti-arrhythmic and anabolic effects. The drug is able to reduce the concentration of free radicals and toxic peroxidation products [15].

The purpose of the research was to determinate the pathogenetic role of LPO and effectiveness of flavonol quercetin in the development and course of experimental bacterial-immune periodontitis.

This is an open-access article distributed under the terms of the Creative Commons Attribution-NonCommercial 4.0 International License, which permits unrestricted use, distribution, and reproduction in any medium for non-commercial purposes, provided the original author and source are credited, a link to the CC License is provided, and changes - if any - are indicated. 


\section{Materials and Methods}

The investigation was performed using white clinically healthy rats weighing $150-200 \mathrm{~g}$ in the conditions of vivarium. The experiments were carried out in accordance with the general rules and provisions of the European Convention for the Protection of Vertebrate animals used for research and other scientific purposes (Strasbourg, 1986), the General Ethical Principles of animal experimentation (Kiev, 2001). The experimental animals were randomly selected and divided into three groups: (1) intact animals, control $(n=10) ;(2)$ animals with experimental periodontitis on the $14^{\text {th }}$ day of the study $(n=8)$; and (3) animals with experimental periodontitis on the $14^{\text {th }}$ day of the study, which was introduced with quercetin (corvitin) $(n=8)$. Experimental periodontitis in the experimental rats was made to cause using injection of a mixture of microorganisms diluted with egg protein into the tissue of the periodontal complex [16]. To enhance the immune response, a complete Freund's adjuvant was injected into the rat's paw at the same time. The experimental rats of the third group were treated with water-soluble quercetin (corvitin) in a dose $100 \mathrm{mg} / \mathrm{kg}$ of animal weight intramuscularly for 7 days (from the $7^{\text {th }}$ to the $14^{\text {th }}$ day). On the $14^{\text {th }}$ day, the experimental rats were sacrificed by bleeding under thiopental anesthesia. For further testing, blood serum was selected. The level of oxidative modification of proteins (OMPs; neutral and basic characters), the content of TBA-active products, and the total amount of metabolites of nitrogen (II) oxide were determined in the serum. The results were statistically analyzed using parametric and non-parametric indices [17] in the Excel software (Microsoft, USA) and STATISTICA 10.0 (StatSoft, USA). The reliability of the differences in values between independent quantitative values was determined using a normal distribution according to the Mann-Whitney $U$ criterion [18].

\section{Results}

According to the results of the research, it was established that the contents of OMP of neutral proteins $\left(\mathrm{OMP}_{370}\right)$ increased by 1.35 times $(p<0.01)$ on the $14^{\text {th }}$ day of the experiment as compared to intact group of rats (Table I).

The treatment of experimental rats with antioxidant quercetin, in a dose of $100 \mathrm{mg} / \mathrm{kg}$ for 7 days intramuscularly, led to a decrease in the level of aldehyde and ketone derivatives in the blood serum by 1.07 times $(p<0.05)$ as compared to this group of rats with experimental periodontitis on the $14^{\text {th }}$ day, without correction with flavonol, which contributed to decrease of oxidative stress (Fig. 1). However, indices were higher than the control group (by 1.27 times; $p<0.01$ ).

The OMP of the main character $\left(\mathrm{OMP}_{430}\right)$ was increased in blood serum on the $14^{\text {th }}$ day of the study (by 1.41 times; $p<0.01$ ), as compared to the control group (Fig. 1). In comparison of this indicator with that was found in the rats on the $14^{\text {th }}$ day without correction, it was decreased by 1.15 times $(p<0.01)$. However, its

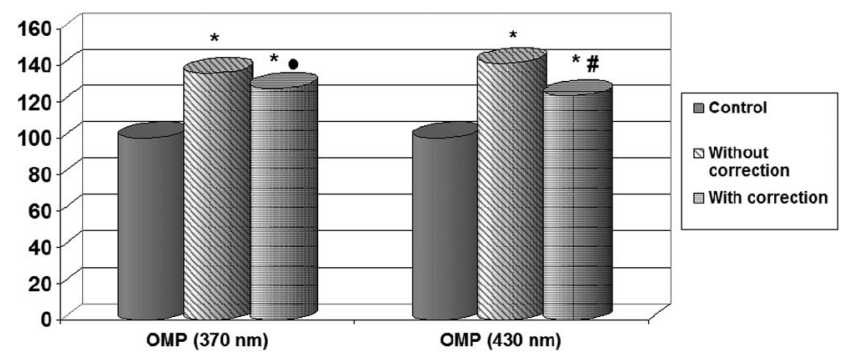

Fig. 1. Changes of $\mathrm{OMP}_{370}$ and $\mathrm{OMP}_{430}$ indices in the rat's serum on the $14^{\text {th }}$ day of the experimental periodontitis and with correction by quercetin (\% of control). *Significant differences in relation to intact rats $(p<0.01)$. " Significant differences in relation to rats with periodontitis on the $14^{\text {th }}$ day of the experiment without correction $(p<0.01)$. - Significant differences in relation to the rats with periodontitis on the $14^{\text {th }}$ day of the experiment with correction $(p<0.05)$

Table I The content of $\mathrm{OMP}_{370}$ and $\mathrm{OMP}_{430}$ in the rat's serum with experimental bacterial-immune periodontitis and correction by quercetin $(\mathrm{M} \pm \mathrm{m})$

\begin{tabular}{lccc} 
& & \multicolumn{2}{c}{ Animals with experimental periodontitis } \\
Experimental form & Control and intact animals & Without correction & After correction with quercetin \\
Experiment duration (days) & - & 14 & 14 \\
Number of rats & 10 & 8 & 8 \\
$\mathrm{OMP}_{370}(\mathrm{~mol} / \mathrm{L})$ & $0.48 \pm 0.02$ & $0.65 \pm 0.01$ & $0.61 \pm 0.02$ \\
& & $p_{1}<0.01$ & $p_{1}<0.01 ; p_{2}<0.05$ \\
$\mathrm{OMP}_{430}(\mathrm{~mol} / \mathrm{L})$ & $0.61 \pm 0.01$ & $0.86 \pm 0.01$ & $0.75 \pm 0.01$ \\
& & $p_{1}<0.01$ & $p_{1}<0.01 ; p_{2}<0.01$ \\
\hline
\end{tabular}

$p_{1}$ : significant differences in relation to intact rats; $p_{2}$ : significant differences in relation to the rats with experimental periodontitis on the $14^{\text {th }}$ day of the research without correction 
Table II The content of TBA-active products and nitrogen (II) oxide metabolites in the rat's blood serum with experimental bacterial-immune periodontitis and correction by quercetin $(\mathrm{M} \pm \mathrm{m})$

\begin{tabular}{lccc} 
& & \multicolumn{2}{c}{ Animals with experimental periodontitis } \\
Experimental form & Control and intact animals & Without correction & After correction with quercetin \\
Experiment duration (days) & - & 14 & 14 \\
Number of the rats & 10 & 8 & 8 \\
TBA-active products $(\mathrm{mcmol} / \mathrm{L})$ & $2.555 \pm 0.092$ & $8.066 \pm 0.143$ & $6.374 \pm 0.045$ \\
& & $p_{1}<0.01$ & $p_{1}<0.01 ; p_{2}<0.01$ \\
$\mathrm{NO}_{2}{ }^{-}+\mathrm{NO}_{3}{ }^{-}(\mathrm{mcmol} / \mathrm{L})$ & $0.028 \pm 0.001$ & $0.147 \pm 0.003$ & $0.081 \pm 0.003$ \\
& & $p_{1}<0.01$ & $p_{1}<0.01 ; p_{2}<0.01$ \\
\hline
\end{tabular}

$\overline{p_{1}}$ : significant differences in relation to intact rats; $p_{2}$ : significant differences in relation to the rats with experimental periodontitis on the $14^{\text {th }}$ day of the research without correction

level was higher in relation to the control group of rats (by 1.23 times; $p<0.01)$.

During investigation, one of the main indicators of LPO activity - the contents of TBA-active products - showed the corresponding changes (Table II). In particular, the formation level of the experimental bacterial-immune periodontitis was higher on the $14^{\text {th }}$ day (by 3.16 times; $p<0.01)$ as compared to the control group.

Treatment with quercetin of the experimental animals from the $7^{\text {th }}$ day to the $14^{\text {th }}$ day of the experiment significantly decreased the content of TBA-active products in the blood serum, as compared to the same period without injections of that drug (by 1.27 times; $p<0.01$ ). Simultaneously, its content in blood serum of researched group remained at high level (Fig. 2), as compared to control values, and was higher (by 2.49 times; $p<0.01$ ).

Contents of unstable products of free radical oxidation and metabolites of nitrogen (II) oxide $\left(\mathrm{NO}_{2}{ }^{-}+\mathrm{NO}_{3}{ }^{-}\right)$in blood serum were significantly increased (by 5.25 times; $p<0.01)$ on the $14^{\text {th }}$ day of the inflammatory process development in the periodontal complex in relation to the control rats (Table II; Fig. 3).

In addition, quercetin effectively reduced the level of NO in the blood serum (by 1.82 times; $p<0.01$ ) than the



Fig. 2. Changes of TBA-active products indices in the rat's blood serum on the $14^{\text {th }}$ day of the research in conditions of development of experimental periodontitis and with correction by quercetin (\% of control). *Significant differences in relation to the intact rats $(p<0.01)$. "Significant differences in relation to the rats with periodontitis on the $14^{\text {th }}$ day of the experiment without correction $(p<0.01)$

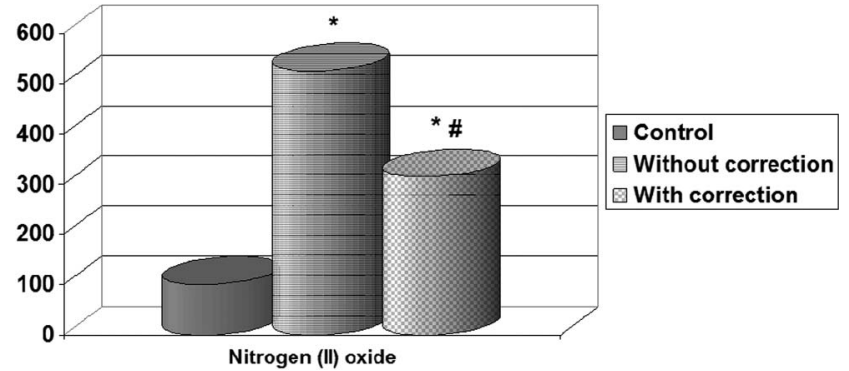

Fig. 3. Changes of metabolites of nitrogen (II) oxide indices in the rat's blood serum on the $14^{\text {th }}$ day of the research in conditions of experimental periodontitis development and with correction by quercetin (\% of control). *Significant differences in relation to the intact rats $(p<0.01)$.

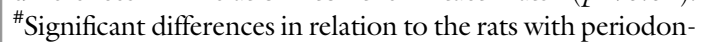
titis on the $14^{\text {th }}$ day of the experiment without correction $(p<0.01)$

rats with experimental periodontitis on the $14^{\text {th }}$ day without correction (Fig. 3). At the same time, this indicator did not reach the values of the control group and was higher by 2.89 times $(p<0.01)$.

\section{Discussion}

The introduction of microorganism mixture in the periodontal tissue with diluted egg protein caused hyperergic inflammatory process with expressive changes in the lower jaw soft tissues, which were accompanied by edema and hyperemia of the mucous membrane and cellular infiltration of surrounding tissues, and manifestations were the same as changes occur in humans [19]. At the same time, reliable changes of LPO activity were established.

An important indicator of free radical processes is the OMPs, in a result of which proteolysis in proteosomes is activated, and alterative processes in the inflammatory area are intensified. OMP products, in comparison with lipid peroxides, are more stable and have the ability to be rapidly metabolized by low-molecular antioxidants and 
peroxidases [20]. The level products of OMPs of main and neutral character in blood serum on the $14^{\text {th }}$ day of the study were increased, as compared to the control group of rats. Taking the effects of this flavonol into account with regard to the indices of the aldehyde and ketone derivatives concentration, this study found that their level was changed in the opposite direction.

The experimental rats treated with quercetin showed a significant increase in the contents of TBA-active products in the blood serum, as compared to the rats without correction at the same period. Simultaneously, their contents in blood serum of the experimental rats remained at the high level, as compared to the control values. This result proved significant activation of lipid peroxide oxidation and accumulation of their products in the inflammatory process development.

The content of unstable metabolites of nitrogen (II) oxide was also significantly increased on the $14^{\text {th }}$ day of research. This provides grounds to state that the inflammatory reaction in the acute period of development is a source of active NO metabolites formation, which are capable to trigger a cascade of free radical processes with their participation. The treatment of experimental animals with the flavonol quercetin resulted in a significant decrease of metabolic product contents of nitrogen (II) oxide in the blood serum. Quercetin effectively influenced not only the course of the inflammatory process in the periodontal tissues, but also reduced the level of NO in the blood serum and thus contributed to the improvement of dynamic balance between the antioxidant defense system and the free radical processes.

\section{Conclusions}

1. In the dynamics of inflammatory process development in the tissues of the periodontal complex with the bacterial-immune component, active products of LPO accumulate that affect the character of the formation, course, and completion.

2. The contents of OMPs of neutral and basic character, metabolites of nitrogen (II) oxide, and TBA-active products in the blood serum increase on the $14^{\text {th }}$ day of the experiment, which indicates an increased activity of free radical LPO.

3 . The flavonol quercetin stabilizes the prooxidantantioxidant system for the course of experimental bacterial-immune periodontitis, which is manifested by a decrease in the neutral and basic OMP content, nitrogen (II) oxide metabolites, and the contents of TBA-active products in the blood serum of experimental animals, thus promoting steady course of inflammatory process.

The authors of this manuscript have certified that they comply with the principles of ethical publishing in
Interventional Medicine \& Applied Science: Szél Á, Merkely B, Hüttl K, Gál J, Nemes B, Komócsi A: Statement on ethical publishing and scientific authorship. IMAS 2, 101-102 (2010).

\section{$* * *$}

Funding sources: No financial support was received for this study.

Author's contribution: AD contributed in the gathering and listing data, the data analysis and interpretation, writing of the article, the idea and the planning of the study, critical review of the article, and final approval of the manuscript. The author has full access to all data in the study and takes responsibility for the integrity of the data and the accuracy of the data analysis.

Conflict of interest: The author declares no conflict of interest.

\section{References}

1. Borisenko A (2013): Periodontal Disease. Medicine, Kyiv, Ukraine, p. 455

2. Dimitrova A, Kolenko Y: Evaluating the effectiveness of various immunomodulators in complex treatment generalized periodontitis in young adults (18-25 years). J Mod Dent 2, 38-39 (2013)

3. Zabolotniy T, Markov A, Shilivsky I (2011): Generalized Periodontitis. GalDent, Lviv, Ukraine, p. 240

4. Tamaki N, Takaki A, Tomofuji T, Endo Y, Kasuyama K, Ekuni D, Yasunaka T, Yamamoto K, Morita M: Stage of hepatocellular carcinoma is associated with periodontitis. J Clin Periodontol 38, 1015-1020 (2011)

5. Verkaik MJ, Busscher HJ, Rustema-Abbing M, Slomp AM, Abbas F, van der Mei HC: Oral biofilm models for mechanical plaque removal. Clin Oral Investig 14, 403-409 (2010)

6. Kaplan JB: Biofilm dispersal: Mechanisms, clinical implications and potential therapeutic uses. J Dent Res 89, 205-218 (2010)

7. Butyugin I, Kornilov N, Abramov O: Comparative analysis of the effectiveness of topical application of antioxidants in the treatment of chronic generalized periodontitis. J Dent 92, 31-34 (2013)

8. Demkovych A: The necrotic-apoptotic changes in blood mononuclear phagocytes in the experimental bacterial-immune periodontitis development. World Med Biol 1, 120-122 (2018)

9. Melnichuk G, Kostyuk I: The evolution of lipid peroxidation and antioxidant protection in the blood serum of children with permanent teeth granulating periodontitis and chronic heightened course, influenced treatment. J Mod Stomatol 3, 25-28 (2012)

10. Nesterov V, Turchenko $\mathrm{N}$ : The structural features of the air-blood barrier in conditions of acute lung hypo- and hyperoxic stress. J Sci 3, 112-116 (2010)

11. Ascenso A, Ribeiro HM, Marques HC, Simoes S: Topical delivery of antioxidants. Curr Drug Deliv 8, 640-660 (2011)

12. Guant T, Song J, Wang Y, Guo L, Yuan L, Gao Y, Lin L, Wang Y, Wei J: Expression and characterization of recombinant bifunctional enzymes with glutathione peroxidase and superoxide dismutase activities. Free Radic Biol Med 8, 188-195 (2017)

13. D'Andrea G: Quercetin: A flavonol with multifaceted therapeutic applications? Fitoterapia 106, 256-271 (2015)

14. Miles SL, McFarland M, Niles RM: Molecular and physiological actions of quercetin: Need for clinical trials to assess its benefits in human disease. Nutr Rev 72, 720-734 (2014) 
15. Williams RJ, Spencer JP, Rice-Evans C: Flavonoids: Antioxidants or signalling molecules? Review. Free Radic Biol Med 36, 838-849 (2004)

16. Demkovych A, Bondarenko Y: Pathogenetic basis periodontitis modeling in rats. Achiev Clin Exp Med 1, 54-57 (2015)

17. Orlov A (2004): Cases Mathematics, Probability and Statistics Basic Facts. MZ-Press, Moscow, Russia, p. 232

18. Berger RL, Casella G (2001): Statistical Inference (2nd ed). Duxbury Press, Florida, p. 182
19. Demkovych A, Bondarenko Y, Hasiuk PA: Oxidative modification of proteins in the process of experimental periodontitis development. Interv Med Appl Sci 9, 218-221 (2017)

20. Medynska KO, Shelyuk OV, Lityuha VV, Omelyanyuk VS: The study of structural characteristics and determine the extent of damage of oxidation-modified rabbit skeletal muscle actomyosin under the influence of ultrasound. Phys Living 18, 164-167 (2010) 